\title{
Tata Air dan Kerentanan Lingkungan Lahan Gambut
}

\author{
Sari Marlina \\ Program Studi Teknik Lingkungan Universitas Muhammadiyah Palangkaraya \\ email: sari.marlina@umpalangkaraya.ac.id
}

\begin{abstract}
ABSTRAK. Tanah gambut memiliki penyebaran yang luas di Indonesia. Lahanlahan dataran rendah di Palau pulau Sumatera, Kalimantan dan Irian umunnyatertutup oleh endapan gambut. Gambut adalah bahan organik setengah lapuk yangterakumulasi di permukaan tanah. Bahan ini bersifat sangat sarang dan koloidal,serta dapat menyerap air sampai dengan salu setengah kali dari berat keringnya.Gambut unumnya terakumulasi pada permukaan tanah yang tergenang atau sangatlembap. Kimia air gamhut dicirikan dengan $\mathrm{pH}$ yang rendah karena tingginyakandungan asam humat. Kandungan nutrisi tanah gambut untuk tunbuhan sangat ditentukan oleh kedalaman lapisan mineral yang mengatasinya. Lahan gambut sering dikeringkan unuuk dimanfaatkan sebagai lahan pertanian dan hunian. Pengeringanlahan gambut dengan drainase yang terlalu dalaim dapat mengakibaikan penurunanmuka lahan sebagai akibat pemampatan, oksidasi dan erosi. Gambut keringmerupakan bahan bakar yang baik, sehingga pengeringan lahan yang berlebihan dapat menyebabkan mudahnya terjadi kebakaran lahan dan hutan.
\end{abstract}

Kata kunci : gambut, tata air, kesuburan, drainase, bahan batar, kebakaran hutan

\section{PENDAHULUAN}

Lahan-lahan gambut di Indonesia memerlukan perhatian khusus karena luasannya, potensí pemanfaatannya, serta kerawanan linngkungannya. Luas lahan gambut di Indonesia diperkirakan sekitar 27 juta ha tersebar terutama di dataran rendah daerah pesisir. Sekitar 16.6 juta ha di antaranya adalah endapan dengan kedalaman gambut lebih dari $1 \mathrm{~m}, 8,8$ juta ha dengan dengan kedalaman lebih dari $2 \mathrm{~m}$, sedangkan sisanya memiliki kedalaman di atas $3 \mathrm{~m}$ (Prasodjo, 1995). Dari sisi luas penyebaran, Indonesia merupakan negara yang memiliki daerahtutupan lahan gambut terluas di daerah tropis, dan negara keempat terbesar di dunia setelah bekas Negara Uni Sovyet, Canada, dan Amerika Serikat.
Gambut dan tanah gambut memiliki beberapa fungsi. Lahan gambut yang subur dapat direklamasi menjadi lahan pertanian, sedangkan yang kurang subur umumnya dimanfaatkan sebagai lahan kehutanan dandaerah lindung untuk penyangga hidrologi. Sebagai bahan, gambut juga memiliki kegunaan yang bernilai untuk industri, seperti misalnya sebagai media pembibitan, bahan baku untuk karbon aktif, penukarkation, dan sumber energi. Sementara itu, lingkungan gambut memiliki keterbatasan terutama dalam hal kesuburan tanah dan rentan terhadap terjadinya kebakaran hutan dan lahan di musim kemarau.

Studi intensif lahan gambut baru mulai dilakukan pada dekade tahun 1970-an seiring dengan peningkatan kebutuhan lahan untuk perluasan pertanian (Driessen et al. 1977), 
yang kemudian dikuti oleh studi lainnya yang menyangkut potensi kayu dan energi serta masalah lingkungan. Penambahan yang berarti untuk pengetahuan dan pengertian tentang lingkungan gambut diperoleh setelah dilakukan serangkaian penelitian di daerah ini dalam rangka kerja sama LIPI-JSPSHokkaido University pada tahun 1997-2003. Tulisan ini ditujukan untuk memberikan gambaran umum tentang kondisi lingkungan daerah gambut beserta keterbatasanya yang penting untuk diperhatikan, berdasarkan pengetahuan yang sampai saat ini telah diperoleh.

\section{PEMBAHASAN}

\section{Kejadian dan Sebaran Gambut Di Indonesia}

Lahan gambut tersebar luas di Pulau Sumatera, Kalimantan, dan Irian Jaya. Pembentukan daerah gambut sangat berhubungan dengan sejarah perubahan muka air laut. Para ahli sepakat bahwa kenaikan muka air laut setelah zaman es (glasiasi terakhir)berakhir pada sekitar 5000 tahun yang lalu dan semenjak itu muka air laut relatif tetap pada ketinggian yang dijumpai saat ini. Pengendapan sedímen yang terangkut aliran sungai di daerah pantai dan muara, yang tadinya tumbuh secara vertikal mengikuti kenaikan muka laut, setelah muka laut tetap berubah pertumbuhannya menjadi lateral ke arah lepas pantai.

Bentangan tanah rawa yang sekarang tersebar di daerah pesisir terbentuk karena sungai-sungai yang terbendung oleh naiknya air laut pada zaman glasiasi. Karena luah yang besar, air sungai yang tertahan oleh pasangair laut tersebut meluap menggenangi tanggultanggul dan bantarannya. Arus sungai yang telah kehilangan kecepatannya akan lebih banyakmengendapkan sedimen berukuran halus (liat atau debu), sedangkan sedimen kasar yang akan diendapkan pada daerah yang berenergi tinggi.Dengan mekanisme seperti ini maka dasar daerah tergenang akan terlapisi oleh sedimen halus yang bersifat relatif kedap air sehinggaterbentuk rawa yang permanent. Vegetasi penutup lahan di atasnya menyesuaikan dengan evolusi lingkungan bermula dari mangrove (tergantung pada salinitas) yang kemudian beralih menjadi hutan rawacampuran, sejalan dengan proses progaradasi pantai.

Lahan gambut terdistribusi pada area endapan tersier, dan sejak miosen keseluruhan komposisi vegetasi rawa gambut tidak begitu banyak berubah (Muller, 1975), Studi di sepanjang Sungai Batanghari(Cameron dkk., 1980) di Sumatera menyimpulkan bahwa kontak antara batuan tersier-pleistosen dengan endapan delta muda yang membentang sampai tepi laut terletak di sekitar Jambi. Saluran sungai pada batuan tersier tertutup oleh endapan gambut yang secara setempat membentuk kubah (peatdome) ombrogen. Endapan gambut tertua berumur 7.300tahun. Batanghari dan anak-annk sungainya terus mengalir dan menggerus tepian serta kubah gimbut yang terbentuk kemudian dan menggeserkan alirannya di atas aluvium yang baru. Di daerah ini, gambut yang terbentuk di belakang tepian dan pada kubah memiliki kedalaman $7 \mathrm{~m}$ dan terbentuk dalam kurun waktu 4.300 tahun

Akumulasi gambut dimulai dengan adanya permukaan lahan yang tergenang atau basah, bahan organik berlimpah dan kecepatan produksinya melebihi kecepatan pelapukannya. Muka air tanah yang tinggi akan menghambat dekomposisi aerob sisa tumbuhan, kemudian menumpuk menjadi gambut. Gambut yang terakumulasi pada cekungan disebut gambut topogen (topogenous peat) atau gambut air tanah (groundwater peat). Apabila cekungan dangkal maka endapan gambut akan segera muncul ke atas permukaan air dan kemudian bertambah tinggi dan tidak tergenang lagi. Gambut yang tubuh endapannya di atas muka air tanah dinamakan gambut ombrogen (omibrogenous peat).

Beberapa endapan gambut, umumnya gambut topogen, seringkali mendapat pengayaan nutrisi yang dibawa oleh aliran air dari bagian hulunya. Kedalaman gambut dengan nutrisi yang diperkaya aliran air seperti ini bisa membentuk endapan yang dalam, terutama apabila pengendapannya diuntungkan oleh adanya pergerakan tektonik lahan secara berangsur. Adapun gambut ombrogen umumnya tidak lagi mendapat pengayaan mineral nutrisi dari aliran air 
karena sebagian besar kandungan air hanya berasal dari air hujan. Pelapukan pada gambut ombrogen inipun terhambat karena tingginya kelembapan secara permanen di bawah tutupan rapattajuk hutan dan muka air tanah dangkal yang biasanya stagnan.

Kecepatan akumulasi gambut tergantung pada beberapa faktor, di antaranya jenis vegetasi, tingkat perkembangan gambut, dan beberapa faktor luar lainnya. Kecepatan ini tampaknya semakin lama akan semakin berkurang. Pada permulaan pembentukan endapan gambut bertambah rata-rata $2,5 \mathrm{~s} / \mathrm{d}$ $4,5 \mathrm{~mm} /$ tahun dan hanya kira-kira 0,5 $\mathrm{mm} /$ tahun pada gambut ombrogen yang sudah berkembang. Bahan mineral batuan atau tanah yang paling umum dijumpai mengatasi endapan gambut ini adalah endapan pasir kuarsu yang merupakan horizon bahan sisa pencucian tanah podzol dan endapan marin halus yang memiliki fenomena tanalh sulfat masam.

Pada kondisi alami, lahan gambut daerah tropis selatu ditutupi oleh hutan. Jenis hutan yang paling khas adalah hatan kerangas di mana tanaman rengas (Gluttarenghas) merupakan spesies pohon yarng dominan. Spesies lainnya beragam dari suatu tempat ke tempat lainnya tergantung dari kondisi ekoflisiologisnya, misalnya semakin dekat ke laut maka spesies mangrove semakin banyak tumbuh, Umumnya hutan gambut memiliki keragaman kayu yang baik, misalnya di Riau, hutan gambut umumnya memilíki 31-30 spesies knyu. Seringkali gambut memiliki kayu yang bernilai ekonomi tinggi atau jenis kayu hutan yang dilindungi.

Dari sisi fauna, hutan gambut merupakan habitat berbagai binatang, dan banyak di antaranya yang merupakan spesies yang dilindungi, seperti burung rangkong (Buceroabicornia, Graculareligiosa) atau binatang menyusui (Manisjavanica, Cerrus unicolor, and Panthera tigris).

\section{Sifat Fisik Gambut}

Gambut di alam dijumpai sebagai pasta berwama coklat kehitaman yang mengandung banyak serat dan sisa tumbuhan dengan proporsiyang sangat ditentukan oleh tingkat pelapukannya. Gambut adalah bahan organik setengah lapuk yaag sangat sarang. Kesarangan totalgambut tropis berkisar antara 75 sampai 85\% (Driessen, 1977). Kerapatan jenis (specific denailty) pambut berkirsar antarn 14 sampai 1,8 tergantung pada kandungan mineral di dalamnya, dan rata-rata umumnya sekitar 1,43 g/em' untuk gambut murni Berat jenis gambut tropis berkisar antara 0,03 sampai $0,4 \mathrm{~g} / \mathrm{m}^{3}$ dan sangat tergantung pada kandungan mineral dan kamampstan (packing) nya. Gambut segar yang lembap memiliki sifat keloidal yang hidrofil (mengikat air) yang membuat massa gambut dapat menaian air sekitar delapan kali dari volumenya. Kebanyakan tanah gambut yatig masih belum tersentuh dijumpai dalam keadaan basah dengan muka air yang dekat atau di atas permukaan tanah.

Pada gambut yang masih muda bahan gambut masih memperlihatkan bentuk dan sifat bahan pembentuknya (batang, daun, akar, dan sebagainya) karena banyaknya serat yang dikandungnya (> 60\%). Gambut yang berserat ini dinamakan gambut fibrik (fibrous peat) olehpara ahli tanah. Pada tingkat pelapukan yang lebih lanjut, di manajumlah serat lebih sedikit daripada matriksnya, sifat gambut ini disebuthemik (hemicpeat). Adapun saprik (sapricpeat) dipakai untuk menamai gambut yang sudah tidak lagi memperlihatkan bentuk serta sifat bahanpembentuknya.

Sifat-sifat fisik gambut memiliki keterbatasan-keterbatasan bagi pertumbuhan tanaman (Driessen, 1977) sebagai berikut yaitu:

1. Penurunan permukaan sctelah didrainase atau pembukaan tutupan lahan;

2. Konduktivitas hidraulik horizontal yang sangat cepat dan konduktivitas vertikal yang sangat lambat secara setempat;

3. Mengandung bahan-bahan yang organik (batang kayu) yang belum melapuk;

4. Daya sangga yang sangat rendah; kenyataan beberapa pohon yang berat di bagian atasnya cenderung untuk tumbang setelah tumbuh sampai ketinggian tertentu;

5. Cepat teroksidasi dan terdekomposisi. 


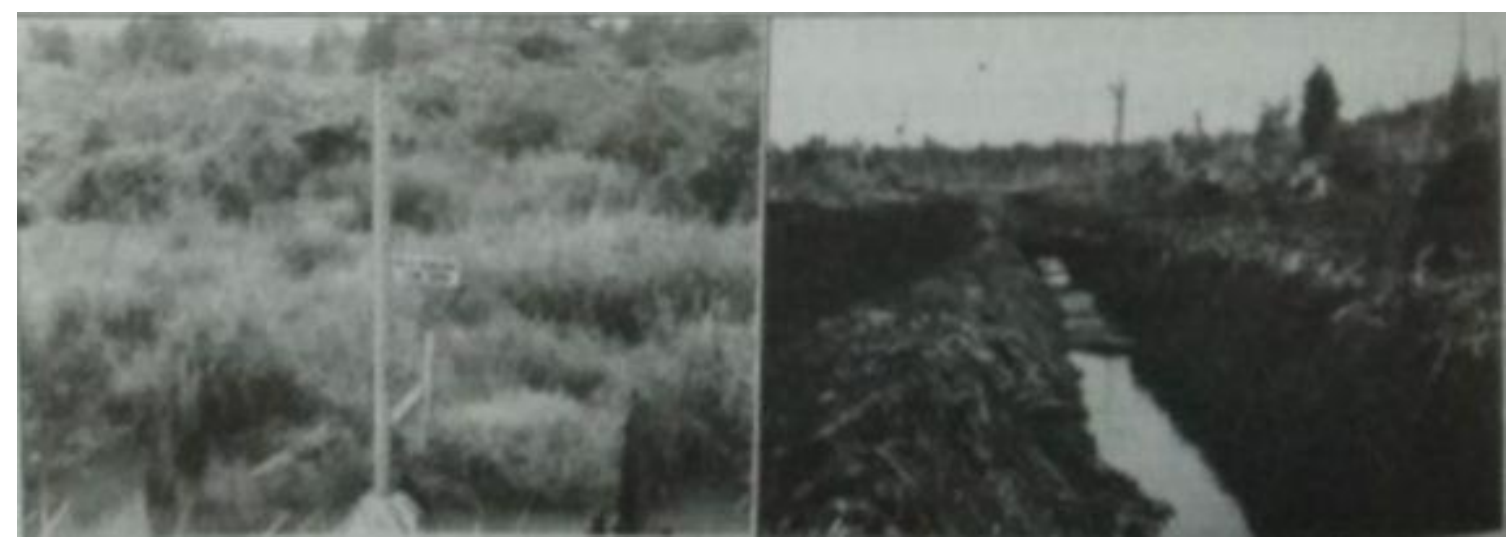

Gambar 1. Lahan gambut sebelum (kiri) dan setelah (kanan) direklamasi

Penyusutan volume yang irreversible menyebabkan menghilangnya daya mengikat air serta meningkatkan sensitivitas terhadap erosi.

\section{Hidrologi Daeraih Gambut}

Endapan gambut umumnya terletak pada daerah rendah yang relatifdatar. Aliran utama sungai-sungai besar yang mclalui dataran gambut umumnya memiliki pola yang berkelok-kelok dengan banyak saluran berbentuk tapal kuda (meander) yang terputus-putus, Mata air sungai utama ini sebagian besar bersumber dari daerah bukan gambut yangberada jauh di hulu. Sedangkan sumber-sumber air yang keluar didaerah gambut keluar di daerah lereng kibah gambut dan kemudian mengalir melalui saluransaluran kecil menuju sungai utama, Kumpulan alur-alur anak sungai di daerah mata air gambut biasanyamemperlihatkan pola aliran radial.

Kapasitas infiltrasi kubah gambut umumnya cukup besar untuk mencegah terjadinya air limpasan pada setiap hujan (Wosten danRizema, 2003). Tetapi hanya bila gambut telah jenuh air, maka setiaphujan berikutnya akan langsung berubah menjadi air limpasan danmengakibatkan banjir atau genangan. Endapan gambut megandungpresentasí bahan kasar sisa tumbuhan ynng tinggi schingga kesarangantotalnya mencapai $80-90 \%$ dengan kesarangan drainase yang bisamencapai $80 \%$. Dengan besarnyakesarangan tersebut, gambut memiliki perneabilitas yang tinggi pula. Konduktivitas hidraulik bahan gambut umumnya di atas I $\mathrm{m} /$ hari pada gambut yang terhumifikasi dengan kedalaman muka air tanah $50 \mathrm{~cm}$. Kenaikan air kapiler pada gambut amat tergantung pula pada humifikasi, Umumnya proporsi pori kapiler di dalam gambut yang tersedia untuk transpirasi tanaman hanya berkisar sekitar $10 \%$. Denganjumlah ini, maka beberapa jenis akan mulai memperlihatkin gejala stress apabila bujan tidak turun selama 10 hari berturutturut.

Sifat fisik massa gambut yang sangat sarang memberikan efek penyangga yang baik terhadap fluktuasi aliran air sebagai responsterhadap curah hujan. Sifat "spongious" hutan tropispada hutan gambut yang juga bertindak scbagai penampungan air bagi daerah di hilirnya. Selama batas jenuh belum terlampaui, maka hutangambut merupakan kawasan penampung air yang sangat besar kapasitasnya. Tetapi apabila kejenuhan telah terlampaei maka fluktuasi aliran permukaan, sebagai respons terhadap curah hujan, akan terjadi amat langsung (Kayama t.al, 2000). Tingginya permeabilitas lateral pada pusat kubah serta lapisan tanah mineral alas yang relatif kedap, maka hujan yang terus menerus akan menimbulkan aliran air permukaan yang besar yang melalui saluran air sering menyebabkanpula terjadinya aliran puncak sesaat pada luah air permukaan di alur air rawa. Sungai-sungai di daerah gambut umumnya memiliki aliran yang tenang dengan variasi kecepatan yang relatif lemah. Perubahan luah air sungai hanya sedikit memberi indikasi terhadap perubahan kecepatan arus. Fluktuasi luah aliran air hanya terlihat pada perubahan tinggi muka air permukaan (Hasegawa et, al.. 2003). Di 
samping perubahan luah aliran air tawar dari hulu, daur harian pasang-surutmuka air laut mempengaruhi pula tinggi muka air sungai sampai lebih dari $100 \mathrm{~km}$ jauh ke darat (Hasegawa, 2005). Keadaan di atas memperlihatkan bahwa aliran air dari daerah hulu ke hilir tidak hanya terjadi melalui aliran air permukaan saja, luah aliran air yang mengalir di bawah permukaan tanah (subsurface flos) cukup besar proporsinya.

Sebaliknya, pengaruh curah hujan terhadap fluktuasi air tanah terjadidemikian langsung. Kenaikan muka air tanah terjadi segera setelah hujan turun, dengan rasio kenaikan muka air tanah terhadap tinggi curah hujan yang mencapai hampir tiga kalinya (Takahashi, 2000). Muka air tanah akan turun secara berangsur setelah hujan reda dengan kecepatan yang semakin lama semakin berkurang. Pada proses penurunan mukaair tanah, faktor-faktor evapotranspirasi lebih banyak berpengaruh daripada pengaliran air tanah. Pada tanah terbuka, besarnya angka evapotranspirasi bervariasi setiap harinya, berkisar antara 0,8 sampai $3,9 \mathrm{~mm} /$ hari (Takahashi, 2000) dan berkorelasi baik dengan total radiasi matahari yang sampai ke permukaan tanah. Sedangkan pada daerah yang tertuatup vegetasi, faktor transpirasi tanamn lebih menentukan terhadap kehilangan air dari dalam tanah. Pada lahan terbuka kelembapan tanah berkurang dengan drastis, sedangkan pada lahan yang ditanamai kelembapan tanah relatif tetap terjaga (Sato et. Al., 2003). Neraca air daerah gambut (Kayama, 2000) memperlihatkan bahwa kehilangan air melalui penguapan dan pengaliran air terhadap totatcurah hujan relatif sebanding.

\section{Kimia dan Kesuburan Gambut dan Air Gambut}

Secara kimia sebagian besar bahan gambut adalah bahan organik amorf yang dapat dibedakan sebagai bahan organik terlarut dan baban organik tidak terlarut. Bahan organik terlarutnya adalah asam-asam hasil pelapukan yang didominasi oleh asam humat dan asum fulvat.

Umumnya gambut lebih miskin unsur nutrisi tannman dibandingkandengan tanah mineral. Rendahnya kandungan mineral di datam gambutmerupakan faktor pembatas kesuburan. Gambut yang dangkalumumnya tidak terlalu miskin akan hara dibandingkan dengan gambutyang dalam. Kekurangan hara paling berat adalalt pada gambut ombrogenous yang tua, sedangkan pada gamput topogen kekurangan hara akan terkoreksi oleh adanya pasokan hara bersama aliran air daridaerah hulu. Apabila gambut terakumulasi sangat tebal, lapisan tanahmineral yang tertimbun akan berada di luar jangkauan akar vegetasi, maka jumlah hara tanaman pada gambut menjadi semakin terbatas dantumbuhan harus bertahan pada kondisi siklus hara yang semakin lamamakin berkurang. Dengan berjalannya waku, maka kehilangan hara dari sistem terjadi pula melalui fixasi atau pencucian, yang menyebabkan pengurangan mineral.

Vegetasi alami akan beradaptasi dengan keadaan ini, ditandai dengan semakin sedikitnya jenis tumbuhan yang dijumpai, dan pada akhirnya tergambarkan di bagian pusat dari kubah gambut ombrogenik yang hanya ditumbuhí oleh pepohonan yang kerdil. Batas pertuimbuhan vertical gambut ini disertai pula dengan perluasan pertumbuhan lateral, yang menerangkar bentuk kubah endapan gambut dataran rendah. Daerah pusat gambut yang miskin hara dan stagnan dikelilingi oleh gambut yang lebih dangkal dan subur pada dataran yang memiliki kemiringan.

Tanah mineral yang mengalasi gambut amat menentukan pula kesuburan lahan gambut, terutama apabila gambut di reklamasi. Mineral-mineral tanah tertimbun akan merupakan pula sumber unsur hara endapan gambut di atasnya apabila gambut mendangkal. Tetapi pada umumnya, tanah mineral yang mengalasi gambut adalah endapan pasir yang hamipir kuarsa mumi schingga miskin akan kandungan hara atau endapan lumpur marin yang mengandung sulfida yang akan menghasilkan kemasaman yang tinggi apabíla teraerasi.

Kenampakan fisik khas air gambut dicirikan ofeh warna larutan kuning-coklat yang kepekatannya memberikan gambaran tentang kualitas airnya. Warna kuning-cok lat air gambut disebabkan oleh kandunngan 
bahan organik terlarut yang dihasilkan dari pelapukan sisa tumbuhan. Kualitas air gambut berbanding terbalik dengan kepekatan bahanorganik terlarut. Ciri lain dari air gambut adalah keasaman yang tinggi.Bahan organik terfarut di dalam air tersebut umumnya dalam bentuk asam organik hasil dekomposisi tumbuhan berupa asam, sehingga semakin tinggi kandungan bahan organik, semakin pekat wama air dan kemasaman semakin meningkat. Umumnya air gambut memilikipH di bawah 6 sedangkan pada air gambut yang pekat nilai $\mathrm{pH}$ bisa mencapai 3.5 (Page, 1997; Djuwansah, 2001). Ciri lainnya adalah kandungan unsur-unsur mineral yang sedikit. Nilai DHL yang menunjukkan jumlah ion-ion terlanut berkisar sekitar 50 i S. Page (1997) menyatakan bahwa kandungan kation dan anion ( $\mathrm{Na} \mathrm{K}, \mathrm{Ca} . \mathrm{Mg}$ ) $\left(\mathrm{HCO}_{3}, \mathrm{H}_{2} \mathrm{SO}_{4}, \mathrm{HCI}\right)$ utama di dalam air gambut lebih kecil dari yang semestinya terdapat pada air mineral normal untuk nilai DHL yang sama. Sebagian nilai DHL pada air gambut didapat dari daya hantar listrik dari muataun koloid organik.

Komposisi kimia penting lainnya yang khas adalah kandungan unsur mineral. Pada bagian permukaan, kandungan $\mathrm{Ca}$ lebih besar daripada Mg (Page, 1997) sedangkan pada lapisan mineral batuan alas kandungan $\mathrm{Mg}$ lebih besar dari Ca (Djuwansah, 2002). Hal ini memperlihatkan bahwa $\mathrm{Mg}$ berasal dari batuan, sedangkun $\mathrm{Ca}$ berasal dari mineralisasi bahan organik. Air gambut mengandung tilai $\mathrm{CN}$ ratio yang relatif tinggi terutama untuk gambut yang tingkat pelapukannya tinggi. Gambut umumnya memiliki kandungan lostor yang rendah tama bila bahan asal kayunya sedikit.

\section{Reklamasi Lahan Gambut}

Sampai dengan akhir 1960an, lahan gambut belum banyak dimanfaatkan karena medan yang sulit ditempuh oleh lebatnya tutupanvegetasi serta permukaan tanah yang sangat lunak dan hampir selalu tergenang air. Pengetahuan dan pengalaman paling banyak tentang lahan gambut pada waktu itu ada pada petani tradisional suku Bugis dan Banjar yang telah terbiasa membuka lahan gambut di sekitar sungai untuk bercocok tanam.
Prinsip yang dikerjakan untuk reklamasi lahan gambut ini cukup sederhana. Pertama: mendrainase lahan dengan membuat paritparit untuk menurunkan muka air tanah dan kemudian membuka lahan dengan menebangi pohon serta membersihkan tumbuhan di atasnya. Karena area yang direklamasi umumnya tidak luas (1-3 ha) dan terletak di sekitar pematang sungai, maka penurunanmuka airtanah yang dapat dilakukan terbatas, Pada skala ini reklamasi tanah umumnya berhasil. Petani tradisional menggunakan pasang surut air sungai (dan laut) untuk mengairi lahan pertaniannya yang ditanamisayur-sayuran, buah-buahan ataupun padi.

Pembukaan lahan skala menengah (100200 ha) mulai dilakukan padadekade 1970 an, sejalan dengan program transmigrasi dan pencetakan lahan pertanian pasang surut di daerah-daerah delta. Program ini banyakmemberi pelajaran tentang budidaya pada lahan gambut, baik dari sisi kesuburan tanah, teknis pengairan dan pengolahan tanah, kecocokan komoditi sampai dengan pemasaran.

Pembukaan lahan gambut secara besarbesaran pernah ditakukan padalahan 1000.000 ha di propinsi Kalimantan Tengah pada dekade 1990an. Di atas lahan ini, karal-kanal untuk irigasi dan drainase dibuat pada skala yang besar dan pohon-pohon di atasaya dibersihkan. Sejauh ini, keberhasilan proyek ini masih tetap dipertanyakan.

Disamping keterbatasan kesuburan, beberapa masalah yang harus dihadapi berkaitan dengan hidrologi derah gambut adalah terjadinya penurunan maka tanah yang cepat (subsidence) muka air tanah diturunkan. Penurunan muka tanah ini dekarenakan oleh (1) adanya pemampatan gambut di bagian yang dikeringkan dan (2) dekomposisi secara tiba-tiba akan berubah secara irreversible dan kehilangan sifat (oksidasi) gambut menjadi gas karbon. Bahan gambut yang dikeringkan hydrophyl-nya. Dengan berat jenis yang sangat rendah gambut yang telah kering akan mudah dihanyutkan oleh aliran air. 


\section{Gambut dan Kebakaran Hutan}

Bencana kebakaran terjadi semakin sering terjadi di Indonesia dalam 10 tahun terakhir ini. Secara statistik kebakaran hutan paling sering terjadi di daerah gambut dan puncak-puncak gunung apabila musim kering berlangsung amat panjang. Sering dan beratnya kejadian kebakaran hutan di daerah gambut tidak lepas dari sifat gambut yang mudah terbakar apabila kering. Sebagai bahan hasil lapukan sisatumbuhan, gambut merupakan bahan bakar yang baik. Endapan gambut yang tebal dapat di konversi sebagai sumber energi. Gambut ini memiliki nilai energi scbesar 9.000 sampai $10.000 \mathrm{BTU} / \mathrm{lb}$, dan rendah kandungan abunya. umumnya kurang dari 2\% (Prasodio, 1995). Untuk gambut yang berasal dari bahan kayu, kandungan sulfurnya sangat rendah $(<1 \%)$. Di negara-negara Eropa Utara dimana endapan gambut sangat berlimpah (mis: Norwegia dan Finlandia), endapan gambut biasa dipanen untuk dimanfaatkan sebagai bahan baku energi. Di Indonesia studi pemanfaatan gambut sebagai sumber energi telah dilakukan di Kalampangan-Kalimantan Barat dan proyek pilot di Perawang-Riau.

Salah satu faktor penting yang menentukan mudah terbakarnya gambut adalah kelembapan, pada kandungan air $1 \%$, sisa tumbuhan akan merupakan bahan bakar yang tergolong "sangat berbahaya" menurut standar bahaya kebakaran Amerika Serikat (US-kandungan air 25-40\%). Bahan gambut dilapangan bisa kehilangan kelembapannya apabila terjadi penurunan muka air tanah yang disertai dengan penguapan sebagai akibat dari penyinaran sinar matahari secaralangsung.

Kebakaran hutan yang terjadi di lahan gambut tidak hanya membakar pepohonan yang tumbuh di atasnya, tetapi juga membakar gambuat yangsnenjadi media tumbuhnya. Umumnya kebakaran hanya terjadi pada musim kemarau yang panjang dan pada lahan yang muka air tanahnya telah diturunkan dengan drainase buatan. Mekanisme pembakaran tanah ganbut tidak selalu berupa nyala yang membakar di permukaan, tetapi juga berupa perambatan bara pada massa gambut yang terjadi bawah permukaan (Usup, 2005).

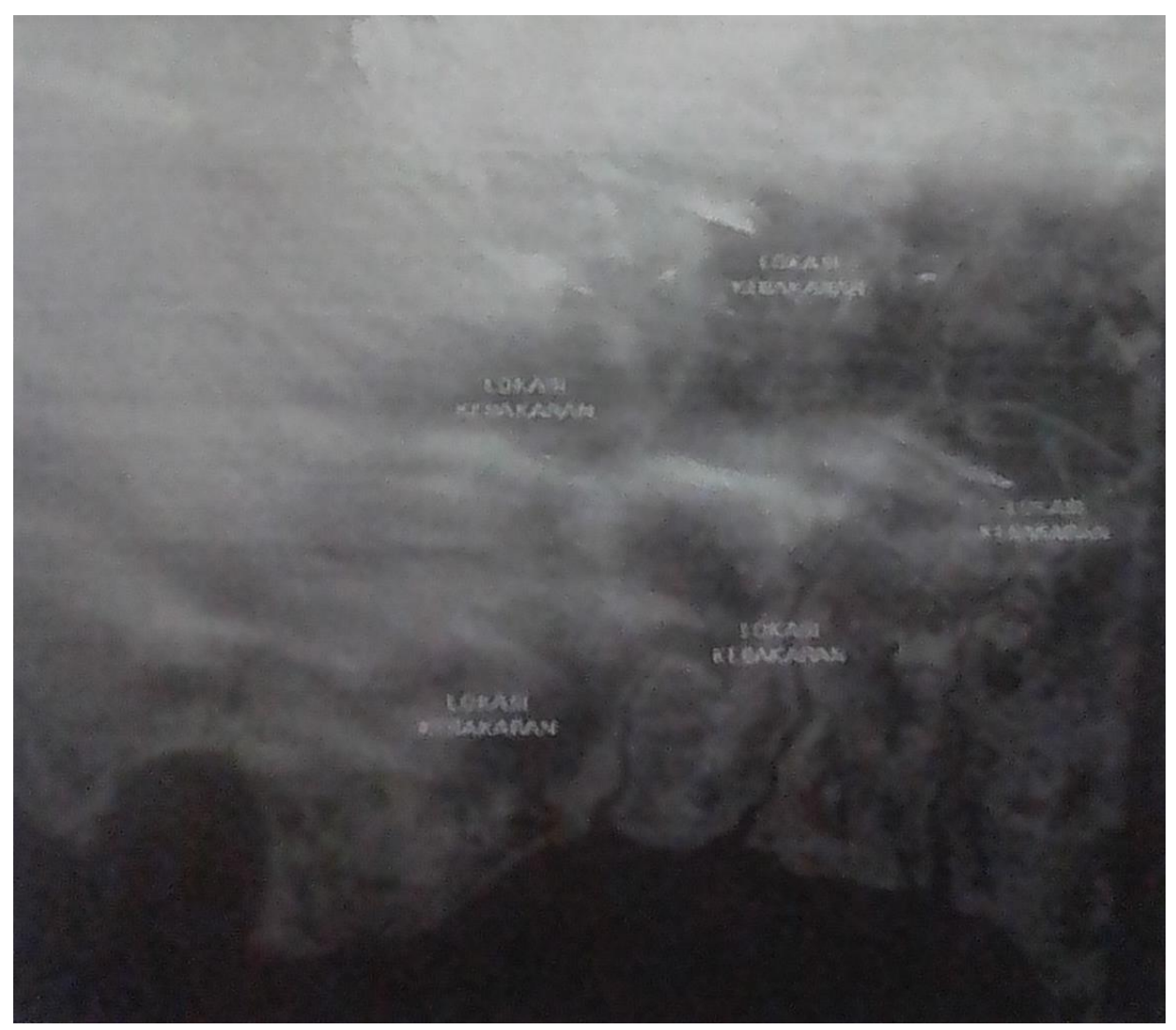

Gambar 2. Citra satelit titik api kebakaran hutan dan lahan di Kalimantan Tengah dan Selatan (LAPAN) 


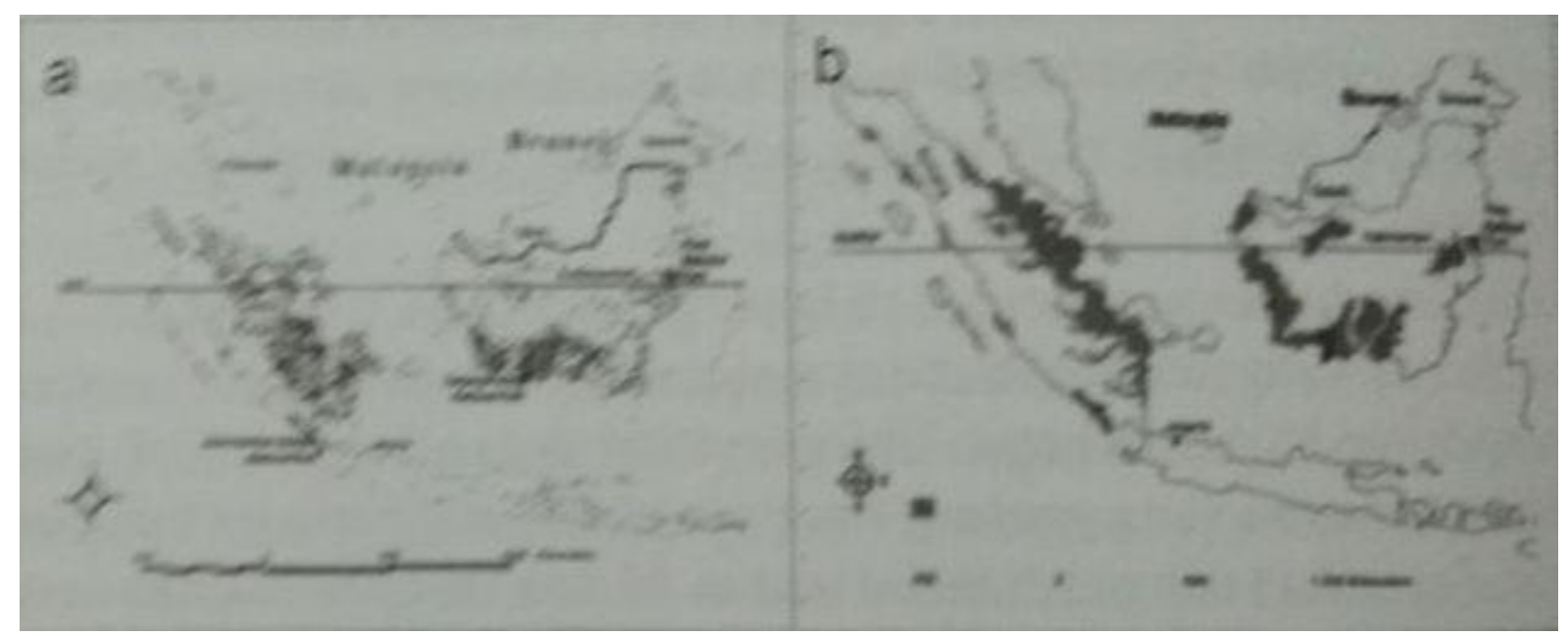

Gambar 3. Sebaran titik api 1997 (a) dan sebaran gambut (b) di Sumatera dan Kalimantan: lebih dari 60 persen kebakaran hutan terjadi di daerah gambut (sumber: LAPAN)

Pembakaran hutan memang merupakan bagian dari budaya pertanian masyarakat tradisional pedalaman di Indonesia. Tetapi masyarakattradisional umumnya telah menguasai cara-cara untuk mengendalikankebakaran hutan agar tidak meluas ke tempat-tempat yang tidakdinginkan. Dalam 10 tahun terakhir ini kasus-kasus kebakaran hutan yang tidak terkontrol semakin sering terjadi, terutama pada musimkemarau yang panjang. Kebakaran hutan pada tahun-tahun terakhir ini telah sampai pada tingkat terbentuknya kabut asap yang menyebar danmencemari angkasa negara-tetangga di kawasan Asia Tenggara. Hasil plotting titik-titik api yang terpantau Citra Satelit LANDSAT(Gambar 3) memperlihatkan bahwa sejumlah kebakaran yang terjadibersamaan pada akhir musim kemarau 1997 mengakibatkan kabut asaphitam tebal yang mengganggu penerbangan di banyak BandaraKawasan Asia Tenggara, berasal dari daerah gambut di Kalimantan dan Sumatera.

Kasus kebakaran hutan dan lahan yang besar dan tidak terkontrol terjadi terutama di daerah-daerah lahan gambut yang telah dibuka dan di drainase untuk menurunkan muka air tanahnya. Pada kondisi seperti itu, bagian permukaan lahan gambut akan banyak kehilangan kelembapannyapada musim kemarau yang panjang yang menguap karena penyinaran matahari yang langsung. Apabila ada api pemicu, makalahan akan segera terbakar dan akan segera pula meluas ke daerah hutan yang juga, pada saat kemarau panjang, memiliki tumpukan serasah kering di atas permukaan tanahnya. Perambatan dan perluasan kebakaranpada lahan gambut sangat sulit dihentikan karena seringkali kebakaran tidak tampak sebagai nyala yang membakar di atas tanah tetapi juga berupa bara yang merambat di bawah permukaan. Salah satu cara untuk mengurangi risiko kebakaran pada lahan gambut yang direklamasi (Takahashi, 2000) adalah dengan mempertahankan tinggi muka air tanah di dekat permukaan.

\section{PENUTUP}

Dengan wilayah penyebarannya yang demikian luas, masih banyak perhatian yang harus kita tujukan terhadap daerah gambut untuk mendapatkan pengetahuan dan pengertian yang cukup lengkap sebagaibekal pengelolaan yang berkelanjutan. Aspek hidrologi tampak memegang peranan penting di dalam sistem lingkungan daerah gambut. Keberhasilan pengelolaan daerah ini akan sangat ditentukan oleh pengaturan tata air yang sesuai dengan daya dukung lingkungannya. Kesalahan pengelolaan wilayah gambut tidak saja akan mengakibatkan hilangnya hutan dan terbengkalainya lahan secara percuma, tetapi lebih jauh dapat mengakibatkan kebakarankebakaran hutan dan lahan yang akan membawa terhadap kerusakan yang lebih parah. 


\section{DAFTAR PUSTAKA}

Cameron, Cornelia C, Supardi, Thomas J. Maltener and Joan S. Esterlie., 1990, Peat resources survey at Dendang and along the BatangHari River from Jambi to coast Sumatra. Spec: Publication Directorate of Mineral Resources, No.31, p.1-23 with 8 figure.

Djuwansah M. and D. Suherman, 2002, Shallow groundwater chemistry of Podzols in Central Kalimantan. Proc. Int. Symp. On Land Management and Biodiversity is South east Asia.

Hasegawa K., A. Mori and H. Sugimoto, 2003, Survey on flow discharge and cross sectional shapes at several sites in the Sebangau River in Dry season 2002, Ann. Rep. Evironmental conservation and landuse change of wettand ecosystem in Southeast Asia, Hokkaido Univ. dan RC for Biologi - Bogor Indonesia.

Hasegawa K, N Sumawidjaya and D, Tanaka, 2005, Time change of electric conductivity of water in Sebangau river due to tidal motion. Ann. Rep. Environmental Conservation and Land Use Management of Wetland iEosystem in South East Asia. Hokkaido Univ. dan $R C$ for Bialogi Bogor Indonesia.

Hehuwat, F., 1982; An overview of peat deposits in Indonesia. Paper presented at Seminar on Peat for Energy Ue, Bandung Indonesa, National Institute of Geology and Mining, p.1-13.

Kayama, M., K. Takahashi and S.H. Limin, 2000, water Balance ofapeat swamp forest in the upper eatchment of Sebangau River. Proc. Int. Symp. On Tropical Peatlands. Siraduate school of enviromental earth sciences Hokkaido University-RDC for Biology LIPI, Bogor.

Muller, J., 1975: Pollen analytical studies of peat and coal fromNorthwest Borneo in Modern Quaternary Research in SoutheatAsia, p.83-86.

Page S., J. Rieley, D. Weiss, S. Gumiri, S. Winarti 1997, Peat andpeatwaterGeochemistry in the upper ctachment of the Sungai Sebangau
Central Kalimantan. Ann, Rep. and Proc. for Int. Workshop on Environmental Conservation and Land UseManagement of Werland Ecosystem in South East Asia. Hokkaido Univ.LIPI-JSPS.

Prasodjo and Mukarwoto, 1995; Developing peat mining in Indonesiaand ecological sustainable prineiples. Indonesían Mining Journal, V.1. No.3, p.78.86.

Sato C., A. Usup, H. Takahashi and S. H. Limin, 2003. Evapopration from a bare soil field and evapopration from a soybeati field in a tropical peatland of Central Kalimantan. Proc. Int. Symp. On Land Management and Biodiversity is South Asia.

Sumawidjaya N. and M. Djuwansah, 1997. Hydrolgy and Engineering aspect of wetland Ecosystem Including Softground Peat inIndonesia.Ann. Rep. and Proc for Int. Workshop on Environmental Conservation and Land Use Management of Wetland Ecosystem in Soulh East Asia. Hokkaido UnivLIPI-JSPS.

Takahashi H., Y. Yonetani and H. Miyasaka, 1998. Micrometeorologicalaspects of tropical peat swamp forest and farmland in central Kalimantan. Ann. Rep. and Proc. for Int Workshop onEnvironmental Conservation and Land Use Management ofWetland Ecosystem in South East Asia. Hokkaido Univ.-LIPI-JSPS.

Takahashi H., A. Usup, C. Sato and H. Hasayaka, 2005. The importantof groundwater control for the prevention of the peat/forest firein tropical peatland.Ann. Rep. Environmental Conservation andLand Use Management of Wetland Ecosystem in South East Asia.Hokkaido Univ dan RC for Biologi Bogor Indonesia.

Usup A., Y. Hashimoto, M. Kamiya, H. Takahashi, and H. Hayasaka,2005: Combustion characteristic of peatland in CentralKalimantan. Ann. Rep. Environmental Conservation and LandUse Management of Wetland Ecosystem in South East Asia.Hokkaido 
Univ dan RC for Biologi-Bogor Indonesia.

Wosten dan Ritzema, 2003. Key aspect of Water management in sustainable development of peatland in Borneo. Proc. Symp. OfLand management andBiodiversity in Southeast Asea. HokkaidoUniv-RC for Biology - LIPI. 